\title{
Religious Radicalism Prevention Model through multicultural Dialog in Pancasila and Civic Education Lectures
}

\author{
Wasino $^{1}$, Edi Kurniawan ${ }^{2}$, Fitri Amalia Shintasiwi ${ }^{3}$ \\ \{wasino@mail.unnes.ac.id ${ }^{1}$, edikurniawan@mail.unnes.ac.id ${ }^{2}$, shintasiwi@mail.unnes.ac.id ${ }^{3}$ \} \\ Universitas Negeri Semarang, Taman Siswa Street, Semarang City, Central of Java, Indonesia ${ }^{1,2,3}$
}

\begin{abstract}
The National Counter-Terrorism Agency (BNPT) released a report that there were seven campuses in Indonesia exposed to radicalism. This research develops a model of Pancasila and CivicEducation lectures directed to prevent radicalism on campuses with a focus on research at Universitas Negeri Semarang and Universitas Samudera, Aceh. This research uses a qualitative approach with document analysis and interviews as well as model development. The results of this research show that Pancasila and Civic Education teaching materials on both campuses did not discuss anti-radicalism education at all. Pancasila Education material was more dominant in philosophical, juridical, and slightly historical aspects. While Civic Education material was also more dominant in discussing legal and political aspects. Social and cultural aspects with multiculturalism or diversity and tolerance materials did not appear in the learning. The lecture did not bring out multicultural dialogue that can give birth to diversity awareness among students. Based on these findings, a model of material that incorporates multicultural and tolerance values as a big frame in Pancasila and Civic Education Learning is proposed.
\end{abstract}

Keywords: multicultural dialogue, Pancasila, civic education, tolerance.

\section{Introduction}

Radicalism is still becoming an issue being discussed in Indonesia today. It proves Eliraz's opinion that radicalism will continue to be an issue that haunts the lives of Indonesian citizens after Suharto's era. Reformation has made Indonesia an open country with its principle of democracy which returns to exist in the relationship of citizens. This thing becomes a gap for radical groups to disseminate their religious and ideological knowledge and doctrines to change the foundational ideology of the nation, Pancasila [1]. According to the report of The National Counter-Terrorism Agency (BNPT) informed by tirto.id, there were seven well-known state universities exposed to radical ideology [2]. The news then disturbed public rationality which considers that campus as a center of knowledge development can be infiltrated by an unscrupulous group of people who spread the radical ideology. Hosen considered that the radical groups did not work individually on campuses, they were organized and massive in disseminating the ideology they believed [3]. The left-wing radical group 
described by the New Order as a representation of the ideology of communism-socialism currently has no room to move due to the great changes occurred in Russia and China. Groups with this ideology are also no longer in demand according to thinkers. Today, the problem is more focused on religious-based radicalism. This is categorized as a right-wing radical group which during the New Order was identified with the hardline Islamic movement [4], [5]. The results of this research illustrate that Islamic propaganda on the campuses not only teaches about Islam as rahmatan lil alamin(a mercy to all creations), but it also tends to political interests of certain groups. This has led to the condition where campuses are currently experiencing a crisis of tolerance. This condition is widespread and represents today's intercultural and interreligious conditions in Indonesia.

One of many ways to ruin humanitarian reasoning is closing the information concerning the diversity and multiculturality of a society tightly [6]. It happens in the process of socialization in the community and formal education. Higher education as a lighthouse which is in charge of providing enlightenment for each nation's problems should not be co-opted by the political interests of certain groups [7]. The process of the emergence of religion-based radical groups co-optation usually starts from the campus propaganda both offline (face to face) and online (digital). Their target is new students. The reason for choosing new students as a cadre of the group is their rationality and knowledge which are considered not as mature as students who have undergone studies. Thus, they will be very easy to influence. From there onwards, radical groups spread their networks within the campus besides giving an understanding of politics and identity which will make the cadres passionate to actively participate in making changes until their ultimate goal to change this nation's foundational ideology is achieved.

Indonesia is a country that has a very large plurality. As an archipelago, ethnic, cultural and religious differences are national assets [8]. This uniqueness is the result of the agreement of the nation's founders who had planned the establishment of a country with multiculturalism as the basis of unity. Therefore, in the context of nationality, Indonesia is final [9], but this has not been interpreted as a great potential for the formation of a peaceful society. As a consequence, this nation easily gets into trouble, both religious radicalism, and ideology. One of the reasons why this nation is easily heated up by the issue of radicalism is the practice and theory of Pancasila and Civic Education which are still not ideal, especially in accommodating the interests of multicultural dialogue oriented to the prevention of religious radicalism.

Therefore, the questions of this research are: 1) how is the condition of learning resources for Pancasila and Civic Education in university? and 2) how is the condition of Pancasila and Civic Education lectures in university? The focus of this research is multicultural dialogue in preventing the ideology of religious radicalism [10], [11].

\section{Method}

The framework of this research is qualitative with a case study design [12]. The case in this research is multicultural dialogue in Pancasila and Civic Education as the prevention of religious radicalism on campus. Religious radicalism on campus is massively socialized through da'wah groups. They do not show themselves and their position to the public, but they take advantage of important moments in campus politics to strengthen their position. Pancasila Education and Civic Education have the potential to accommodate religious and culturalbased tolerance values. Through cultural dialectics, the extent of the role of Pancasila and 
Civic Education in preventing the development of religious radicalism in Universitas Negeri Semarang and Universitas Samudera, Aceh will be seen.

The data source of this research was explored through Focus Group Discussion involving various campus elements, such as student activists from extra and intra-campus organizations, history education lecturers, civic education lecturers, religious education lecturers, Pancasila education lecturers, and Sociology lecturers. It was noted that this research was supported by 15 representatives of student organizations and 9 lecturers from social sciences and humanities. Data analysis of this research used Critical Discourse Analysis (CDA) to examine the discourse of multicultural dialogue in learning resources and the lecture process more deeply [13]. Van Dijk's CDA model is an analysis tool on the use of formal language from written text and spoken words. The formal language used by societies, in general, describes the construction of their thinking and orientation to the future. This research aimed to map how far peace and tolerance could become the guideline in socializing on campuses where Pancasila and Civic Education lectures are taught. CDA was also used to analyze multicultural dialogue conducted by Pancasila and Civic Education lecturers. To find this out, in-depth interviews were conducted. Therefore, a solid narrative concerning the religious radicalism prevention model through multicultural dialogue will be generated. This research produced 6 data transcriptions consisting of 2 categories, namely 3 students and 3 lecturers. Data transcription was shown through coding to simplify the analysis process. Lecturer Data 1 (LD1), Lecturer Data 2 (LD2), Lecturer Data 3 (LD3), Student Data 1 (SD1), Student Data 2 (SD2), and Student Data 3 (SD3).

\section{Results and Discussion}

Today, the academic community in Indonesia is intensively discussing the goals and practices of Pancasila and Civic Education. In principle, both are considered to have the same characteristics. LD2 argues: "Pancasila and Civic Education have the same goal of creating good citizens and understanding the goals and morality of the Indonesian people". Before being separated, both are an integral course, taught to form civil society who understands the law and national outlook on life. Pancasila and Civic Education are currently separated because they specify both the theory and praxis. Pancasila education is directed so that the public understands the principles and ethics of Pancasila, while Civic education is directed to form a society who is aware of the law and morals. In practice, both of them together develop citizenship to realize Indonesian citizens who have civic competence [14] - [16]. Pancasila and Civic Education are currently criticized by many people because it has not been able to accommodate the interests of multiculturalism in learning. Plural aspects of the community have not been a concern for both courses. LD1 argues: "Pancasila education, for me, is political and compelling, because the learning is doctrinaire, not academic. I feel it is taboo for a student to question the values in the Pancasila, for the example divinity". Responding to that, LD3 argues: "Civic Education is formalistic and static so that it is not possible to develop multicultural dialogue. I illustrate the process in Civic Education as the socialization of the constitution and laws that apply in Indonesia without any relation to the social context in society". That is the condition that makes these two courses considered not able to play a role in preventing the idea of religious radicalism which is happening right now.

Referring to Jackson's opinion, Civic education should be able to be a catalyst between civic issues and theory. The practice of learning is the habituation of civic values to shape the 
mentality of the younger generation under the spirit of nationality [17]. Jackson's opinion was supported by Torney-Purta et al, that education that carries the spirit of nationality and citizenship should be directed to address the social issues which are happening in society. Thus, learning is always actual. Today, civic education is taught formally. Therefore, many values and messages are not conveyed. As a consequence, it generates the assumption that such civic education blinds people's eyes to see the reality they face [18]. Jackson's opinion is under the findings of this research that in the textbooks of learning resources for Pancasila and Civic Education today, there is no enthusiasm to build knowledge concerning multiculturalism. Both courses talk a lot of things out of the actual condition of the Indonesian. Moral, ethic, and nationality values conveyed seem classic and are no longer relevant to the spirit of the times, for example, the ethics of citizens. Currently, the lives of citizens are facing two aspects, namely the real world (reality) and the virtual world (digital). Radicalism and violence are rumored not only disseminated in the real world through da'wah but also in the digital world which is one of the aspects utilized by radical groups to gather the masses. This becomes proof that the existing citizenship learning conditions seem outdated and need to be updated in principle.

The process of Pancasila and Civic Education lectures have not used multicultural dialogue as an instrument in developing spirits of tolerance and diversity. SD2 argues: "Pancasila lecture uses discourse method more often. The lecturers use teaching textbooks as the main sources in teaching. In my opinion, it will not develop the students' knowledge. Pancasila is described as a closed ideology. Once, my friend questioned the interpretation of Pancasila, then the lecturer answered that it was unethical because this kind of question tried to disturb the basis of the state". This is very far from the spirit of citizenship. However, students are the generation that needs to be fostered and hold the national leadership relay so that they need to be mentally nurtured and trained to be able to express their opinions. It is under the value of democracy taught by the lectures of Pancasila and Civic Education even it is in the formal domain [15]. SD1 argues: "I do not see civic lectures providing an understanding of the dangers of religious radicalism. Besides, the aspect of diversity has not been included as an object of discussion.

Therefore, the learning is impressed theoretically. To be honest, I think students feel very difficult to learn static material to develop a comprehensive understanding of state and nation. Thus, dialogical learning styles should be needed". The understanding of citizens will grow through critical dialogue [10], [19], [20]. In the context of diversity, the understanding of citizens needs to be fostered through multicultural dialogue. Lecture material needs to integrate with the aspects of Indonesian culture and wisdom in its learning material. SD3 argues: "I agree that Pancasila and Civic lectures need to be fostered through multicultural dialogue. The discussion process that occurs will provide a unique experience in learning. That unique experience will bring the impression that Indonesia is very diverse. Therefore, the diversity that exists should be maintained". Pancasila and Civic lectures must be carried out using a critical approach and should conduct debate, refutation, and acceptance of one's cultural arguments that will generate knowledge concerning the growth of pluralism in religion, nation and state. Arifianto argues that one way to foster anti-religious radicalism is fostering the spirits of cultural pluralism and social solidarity [21]. Pancasila and Civic Education which include the value of cultural diversity will stimulate the spirit of tolerance of the younger generation. 


\section{Conclusion}

Pancasila and Civic Education lectures, today, are still very normative. Therefore, the development of knowledge in lectures is very difficult to achieve. This is proven through the lecture material which in principle contains more theoretical elements than the actual context in society. This makes the learning seem formalistic and stay away from the reality that must be faced like the phenomenon of religious radicalism which is developing rapidly now. Based on the results and discussion above, new formulations are needed for Pancasila and Civic Education lectures. One of the new formulations is relying on the multicultural dialogue model in preventing the religious radicalism on campuses. This multicultural dialogue can be built in two ways, namely: 1) strengthening the lecture material through the integration of cultural and social values in society and 2) the use of reality and religious radicalism phenomena as the objects of direct study both through problem-based learning and discovery learning. Both of them can strengthen Pancasila and Civic Education lectures as well as connect these courses with the reality faced by the community.

\section{References}

[1] G. Eliraz, Islam in Indonesia: Modernism, radicalism, and the Middle East dimension. Sussex Academic Press Brighton, 2004.

[2] A. Sumandoyo, "Radikalisme di Kampus Berkembang Karena Tak Ada Gerakan Tandingan," tirto.id. [Online]. Available: https://tirto.id/radikalisme-di-kampusberkembang-karena-tak-ada-gerakan-tandingan-cPqQ. [Accessed: 29-Sep-2019].

[3] N. Hosen, "Revelation in a Modern Nation-State: Muhammadiyah and Islamic Legal Reasoning in Indonesia," Aust. J. Asian Law, vol. 4, no. 3, p. 232, 2002.

[4] A. Azra, Indonesia, Islam, and democracy: Dynamics in a global context. Equinox Publishing, 2006.

[5] N. Hosen, "Collective Ijtihad and Nahdlatul Ulama," N. Z. J. Asian Stud., vol. 5, 2004.

[6] J. A. Banks, "Teaching strategies for ethnic studies.," 1975.

[7] D. Afrianty, "Islamic education and youth extremism in Indonesia," J. Polic. Intell. Count. Terror., vol. 7, no. 2, pp. 134-146, 2012.

[8] P. Suparlan, "Menuju Masyarakat Indonesia yang multicultural," Antropol. Indones., 2014.

[9] P. Suparlan, "Indonesia Baru Dalam Perspektif Multikulturalisme"," Dalam Hari. Media Indones., vol. 10, 2001.

[10] A. Azra, Globalization of Indonesian Muslim discourse: contemporary religiousintellectual connections between Indonesia and the Middle East. na, 2002.

[11] M. Woodward, I. Rohmaniyah, A. Amin, and D. Coleman, "Muslim education, celebrating Islam and having fun as counter-radicalization strategies in Indonesia," Perspect. Terror., vol. 4, no. 4, pp. 28-50, 2010.

[12] R. K. Yin, Case study research and applications: Design and methods. Sage publications, 2017.

[13] T. A. Van Dijk, "18 Critical discourse analysis,” Handb. Discourse Anal., pp. 349-371, 2001.

[14] R. D. Barr, J. L. Barth, and S. S. Shermis Defining the social studies. National Council for the Social Studies Washington, DC, 1977. 
[15] E. Komara, "Curriculum and Civic Education Teaching in Indonesia," EDUCARE, vol. 10, no. 1, 2017.

[16] E. S. Nurdin, "The Policies on Civic Education in Developing National Character in Indonesia.," Int. Educ. Stud., vol. 8, no. 8, pp. 199-209, 2015.

[17] E. Jackson, "Crafting a new democracy: Civic education in Indonesian Islamic universities," in Muslim Education in the 21st Century, Routledge, 2014, pp. 121-136.

[18] J. Torney-Purta, J. Schwille, and J.-A. Amadeo, Civic education across countries: Twenty-four national case studies from the IEA civic education project. ERIC, 1999.

[19] D. Al Hamdani, "The character education in Islamic education viewpoint," J. Pendidik. Islam UIN Sunan Gunung Djati, vol. 1, no. 1, pp. 98-109, 2016.

[20] N. Hosen, "Religious Pluralism, Inclusive Secularism, and Democratic Constitutionalism," in Muslim Secular Democracy, Springer, 2013, pp. 211-232.

[21] A. R. Arifianto, "Islamic Campus Preaching Organizations in Indonesia: Promoters of Moderation or Radicalism?," Asian Secur., pp. 1-20, 2018. 